\title{
Blended Learning: Kombinasi Belajar Untuk Anak Usia Dini di Tengah Pandemi
}

\author{
Eva Eriani ${ }^{1}$, Reni Amiliya ${ }^{2}$ \\ ${ }^{1}$ PIAUD, STAI Auliaurrasyidin, ${ }^{2}$ PIAUD, STAI Diniyah
}

\begin{abstract}
ABSTRAK
Pandemi covid 19 yang melanda seluruh dunia menyebabkan perubahan diberbagai aspek kehidupan, salah satunya pada bidang pendidikan. Pemerintah, guru, keluarga, bahkan siswa dituntut harus mampu beradaptasi dengan keadaan. Untuk memutus penyebaran virus corona, pemerintah sepakat membuat aturan bekerja dan belajar dari rumah. Karena setengah pembelajaran telah berlangsung secara klasikal, maka setengahnya lagi dirancang untuk dilakukan secara daring, kombinasi pembelajaran ini dikenal dengan istilah blended learning. Karena itulah peneliti tertarik untuk mengetahui apakah blended learning efektif diterapkan di tengah pandemi, mengingat hal ini cukup baru dilakukan terutama pada Pendidikan Anak Usia Dini. Data dikumpulkan dengan menyebarkan angket yang diisi secara daring oleh 30 guru di 5 TK yang melaksanakan blended learning. Data kemudian dianalisis dengan uji coba skala, rumus persentase dan SPSS Versi 16. Hasil penelitian menunjukkan keefektifan penerapan blended learning untuk anak usia dini saat pandemi ini berada pada kategori baik.
\end{abstract}

Kata Kunci: Blended Learning, Pandemi, Anak Usia Dini

\begin{abstract}
Covid 19 pandemic hitting people arround world caused many changes in various aspects of life which one of them is education field. Government, teachers, families, and even students are required to be able to adapt to the situation. Breaking down the corona virus transmission, the government got deal with the rules of working and studying from home. Concerning the previous session of learning classically conducted, it seemed to be agreed that the rests are designed to be accessed online which combination (offlne and online) was so called by blanded learning. That's why the researcher put a high interest on whether it can effectively be applied at pandemic especially for Early Childhood Education. Data was collected through the questionnaires which are onlinely filled out by 30 teachers of 5 kindergartens who carried out blended learning. Data were then analyzed by using a trial scale, percentage formula and SPSS, 16 version. The results showed the effectiveness of the application of blended learning for early childhood when the pandemic was in the good category.
\end{abstract}

Keywords: Blended Learning, Pandemic, Early childhood

Corresponding Author:

Eva Eriani

Email address: evaeriani123@gmail.com 


\section{PENDAHULUAN}

Pandemi virus corona masih terus terjadi diberbagai belahan dunia. Secara umum wabah ini memiliki dampak yang sangat besar terhadap aktivtas dari berbagai aspek di seluruh negara. Peristiwa pandemi bukan pertama kali terjadi, jauh sebelum corona beberapa pandemi buruk yang merenggut banyak nyawa telah terjadi. Corona atau Covid-19 bukan penyakit yang bisa diremehkan, karena beberapa alasan: 1) Penuaran virus Covid-19 baru cenderung mudah terjadi, menurut Center for Diades and Prevention $(C D C)$ Amerika Serikat, virus ini dapat menular melalui kontak dekat dengan orang yang terinfeksi melalui bersin atau batuk, jabat tangan, dan melalui benda yang dihinggapi virus. 2) Covid-19 menimbulkan berbagai komplikasi penyakit hingga kematian, selain menimbulkan gangguan pada saluran pernafasan virus ini juga dapat menimbulkan komplikasi dan masalah organ lain seperti kerusakan hati, kerusakan jantung, gagal gnjal akut, hingga infeksi sekunder. 3) kelompok tertentu lebih berisiko mengalami Covid-19, masih dari CDC orang berusia 65 tahun ke atas rentan untuk mengalami komplikasi dari Covid-19, begitu pula orang dengan kondisi medis tertentu segala usia. 4) belum ada obat yang disepakati untuk penanganan Covid-19. Riset tekait vaksin virus ini masih dalam penelitian dan pengujian oleh para ahli diberbagai negara. 5) Adanya silent spreader atau penularan tanpa gejala. Virus ini bahkan menyerang segala usia, dari usia produktif, lansia, anak-anak hingga bayi dalam kandungan.

Secara nasional, total kasus positif Covid-19 hingga tanggal 11 Mei 2020 Adalah 14.265 orang. Yang dinyatakan sembuh 2.881 pasien dan yang meninggal sejumlah 991. Tidak ada yang mengetahui akan sampai di angka berapa jumlah pasien Covid-19 dan tidak ada yang dapat memastikan kapan pandemi ini akan berakhir. Seiring dengan penyebaran virus corona (Covid-19) yang semakin mengkhawatirkan, menyebabkan berbagai perubahan termasuk pada aspek pendidikan. Pemerintah membuat berbagai kebijakan, salah satunya mengeluarkan surat edaran untuk meliburkan kegiatan belajar mengajar mulai dari tingkat TK hingga perguruan tinggi.

Anjuran "belajar dan bekerja dari rumah" menjadi perhatian khusus bagi setiap lembaga pendidikan untuk mengatur kegiatan belajar mengajar yang efektif. Perubahan pola pembelajaran yang mendadak ini tidak mudah dilakukan, perlu perencanaan dan penyusunan strategi belajar yang aman namun tetap dapat mencapai tujuan pembelajaran. Selain itu sekolah juga harus memaksimalkan SDM yang ada, membekali guru-guru dengan kemampuan yang mumpuni agar pembelajaran dapat berjalan dengan baik.

Pembelajaran yang tadinya dilaksanakan dengan tatap muka, kali ini harus dilakukan dengan sistem daring namun tetap harus mampu menjembatani ruang dan waktu. Permasalahan ini dapat diatasai dengan memanfaatkan teknologi digital. Namun, tentu saja diperlukan pemikirkan bagaimana caranya pembelajaran tetap berlangsung dengan tetap memberikan pengalaman belajar yang efektif, biaya yang 
efisien, serta dapat meningkatkan akses dan fleksibilitas tanpa bertemu secara langsung.

Pembelajaran daring merupakan salah satu jenis pembelajaran jarak jauh. Pembelajaran jarak jauh adalah pendidikan yang pendidik dan peserta didiknya terpisah dan pembelajarannya menggunakan berbagai sumber belajar dari mana saja. Jika melihat situasi dan kodisi yang sedang berkembang, pelaksanaan pembelajaran daring ini sangat relevan. Hal ini diperkuat dengan UU RI Nomor 20 Tahun 2003 pasal 31 ayat 2 yang menyatakan bahwa pendidikan jarak jauh berfungsi memberikan layanan pendidikan kepada kelompok masarakat yang tidak dapat mengikuti pendidikan secara tatap muka atau regular.

UU RI Nomor 20 Tahun 2003 pasal 6 ayat 2 menyatakan setiap warga negara bertanggung jawab terhadap keberlangsungan penyelenggaraan pendidikan. Jika ditelisik lebih dalam, maka yang paling bertanggung jawab untuk anak usia dini adalah orang tuanya, untuk itu orangtua perlu menjalin hubungan baik dengan sekolah. Hal ini diperkuat dengan UU RI Nomor 20 Tahun 2003 pasal 7 ayat 1 yang menyatakan orang tua berhak berperan serta dalam memilih satuan pendidikan dan memperoleh informasi tentang perkembangan pendidikan anaknya. Orang tua dapat bertanya tentang tugas, perkembangan anak, memberi masukan, dan lain sebagainya.

Pembelajaran daring dipercaya dapat memutus mata rantai penyebaran virus corona, namun disisi lain juga memberikan pekerjaan baru untuk orang tua. Orang tua harus menjadi guru untuk anak-anaknya, untuk itu diperlukan kerja sama dan komunikasi yang baik antara pihak sekolah dan wali murid. Karena itu pembelajaran perlu disesuaikan dengan peserta belajar. Jika peserta belajarnya adalah anak usia rendah, maka diperlukan bantuan orangtua untuk mendampingi, menjelaskan, dan mengarahkan anak agar pembelajaran dapat berjalan dengan baik.

Semester genap di kalender akademik mulai dari bulan Januari-Juni, sedangkan virus corona terdeteksi indonsesia semenjak februari. Setengah pembelajaran telah dilakukan secara langsung (tatap muka) dan setengahnya lagi dilakukan secara daring. Kombinasi dari belajar tatap muka dan daring disebut dengan blended learning (Tucker (2012, hal. 79); Bersin (2014, hal. 331); Bielawski \& Metcalf dalam Husamah (2014, hal. 29)). Artinya, pembelajaran dengan pendekatan teknologi dengan mengkombinasikan sumber-sumber belajar tatap muka dan yang dimuat dalam media komputer, telpon seluler, saluran televisi, konferensi video, dan media elektronik lainnya. Siswa dan guru bekerja sama untuk meningkatkan kualitas pembelajaran. Tujuan utama blended learning adalah memberikan kesempatan bagi berbagai karakteristik pebelajar agar dapat belajar mandiri, berkelanjutan, dan berkembang sepanjang hayat, sehingga belajar akan menjadi lebih efektif, lebih efisien, dan lebih menarik. Secara esensi blended learning merupakan kombinasi antara pendidikan dan teknologi (Krasnova (2014, hal. 400) dan Launer (2010, hal. 47).

Namun, apa yang membedakan blended learning dari konsep lain seperti pendidikan berbasis web, pendidikan virtual, e-learning, pendidikan berbasis 
komputer, dan istilah-istilah serupa? Ternyata blended learning bukan hanya kombinasi dari lingkungan nyata dan virtual tetapi kenyataan bahwa kombinasi ini harus didasarkan pada rencana dan kebijakan khusus serta mampu mewujudkan tujuantujuan yang tidak dapat dicapai oleh lingkungan fisik saja (Seraji, Attaran, dan Azizi: 2019, hal. 19). Proses pembelajaran yang hanya menggunakan teknologi tidak dapat sepenuhnya berhasil. Ini karena gaya belajar siswa berbeda dan peran guru dalam kelancaran proses pembelajaran pada dasarnya siswa. Selain itu, para guru tidak memiliki pedoman utama untuk mengidentifikasi sikap konseptual siswa. Dengan demikian, dalam kombinasi lingkungan nyata dan virtual, elemen-elemen seperti teknologi, waktu, tempat, peran, pedagogi, tujuan pendidikan, kemandirian dan dukungan siswa harus dikombinasikan dengan seimbang, sambil mempertahankan dan memperkuat motivasi untuk belajar, sekolah menyediakan lingkungan yang sesuai untuk siswa agar dapat mandiri, refleksi, interaksi, partisipasi, penilaian diri, dan partisipasi.

Secara umum blended learning menerapkan lebih dari satu metode, teknik, strategi dan sumber pembelajaran (Ikhwan \& Widodo, 2014 hal. 54). Guru sebagai fasilitator dasar atau sebagai pengendali utama dari proses sikap pada siswa dengan menerapkan blended learning dan siswa sebagai subjek proses pembelajaran. Staker dan Horn (2012, hal. 23) mempresentasikan blended learning dalam empat model: 1) Rotation Model, model dimana siswa beraktivitas belajar dari satu tempat pusat belajar ke pusat belajar lainnya sesuai dengan jadwal atau RPP yang telah ditetapkan oleh. Siswa belajar dalam siklus aktivitas belajar, misalnya mengikuti KBM di kelas, diskusi kelompok kecil, belajar daring, termasuk mengerjakan tugas bersama secara kolaboratif, lalu kembali lagi belajar di kelas. 2) Flex Model, model dimana rencana pembelajaran dan materi pembelajaran telah dirancang secara daring dan diletakkan di fasilitas e-learning. Aktivitas belajar siswa terutama dilakukan secara daring. Guru akan memberikan dukungan belajar tatap muka di kelas secara fleksibel, saat memang diperlukan oleh siswa. 3) Self-blend Model, model dimana siswa secara mandiri berinisiatif mengambil kelas daring baik di sekolah maupun di luar sekolah. Kelas daring yang diikuti oleh siswa tersebut untuk melengkapi kelas tatap muka di sekolah. Siswa menggabungkan sendiri kegiatan belajar daring dan kegiatan belajar tatap muka di kelas. 4) Enriched Virtual Model, model dimana siswa satu kelas belajar bersama-sama di kelas dan di lain waktu belajar jarak jauh dengan sajian materi pembelajaran dan tatap muka dengan guru secara daring. 


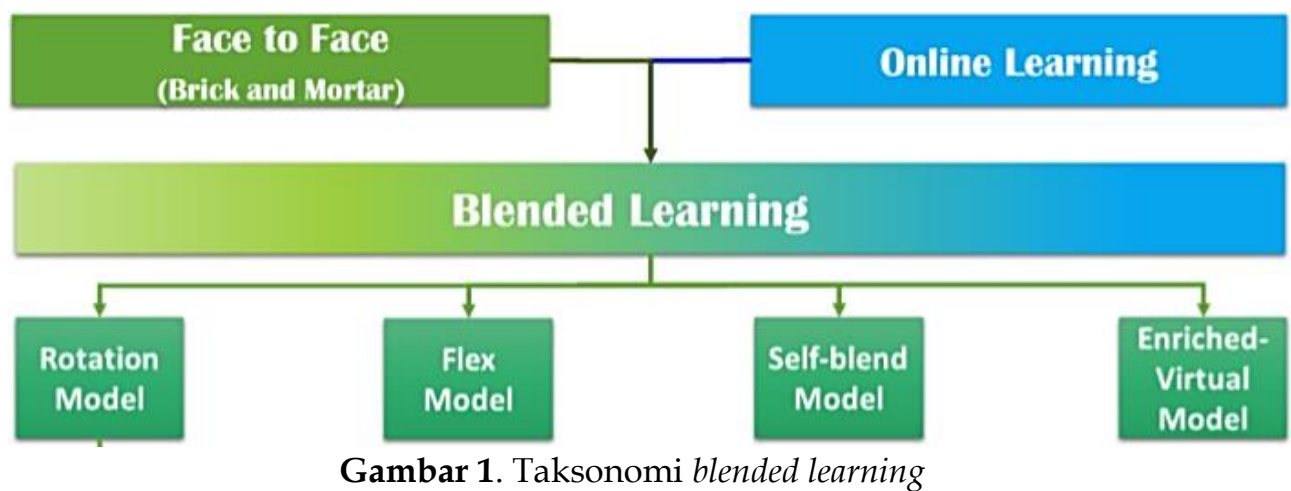

Jenis blended learning yang dilakukan secara umum di TK pada saat pandemi ini adalah enriched virtual model dengan pertimbangan tidak ada kontak fisik antara guru dan siswa serta melihat subjeknya adalah anak usia dini yang masih perlu pendampingan keluarga. Berdasarkan beberapa penelitian ternyata blended learning dapat menstimulasi kognitif, afektif, dan perilaku/sikap anak (mandiri \& tanggung jawab), fisik, serta emosional (Dziuban 2016, hal. 45; Dziuban 2017, hal. 33; Dziuban 2018 hal. 12; Ikhwan 2014 hal. 60; Picciano 2014 hal. 65; Lalima 2017 hal. 134; Atlay, 2019 hal. 135). Kegiatan belajar mengajar di kelas sangat membantu dalam tingkat memori dan tingkat pemahaman sehingga membantu dalam pengembangan ranah kognitif dan pada saat yang sama perilaku guru, pengalaman bermain, dan kelompok sosial dengan teman-teman sekelasnya mengembangkan ranah afektif dan fisik. Sementara pengalaman daring membantu dalam tingkat pembelajaran reflektif memungkinkan siswa untuk secara ekstensif mempraktekkan secara mandiri apa yang telah mereka pelajari dalam instruksi di tempat tanpa keterbatasan waktu dan tempat. Namun, apakah blended learning efektif diterapkan pada Pendidikan Anak Usia Dini?

\section{METODE PENELITIAN}

Penelitian ini menggunakan metodologi kuantitatif yaitu penelitian berdasarkan data secara empiris dan sistematis yang dapat diukur dengan angka. Waktu penelitian dilakukan pada bulan Februari hingga Mei 2020, subjek dalam penelitian ini adalah 30 orang guru di 5 sekolah yang melakukan program PFH. Indikator dan instrumen ini dikembangkan dari penilaian lingkungan blended learning menurut Boelens, Wever \& Voet (2017, hal. 10) yang dipadukan dengan Ikhwan \& Widodo (2019, hal. 58) kemudian dideskripsikan menjadi rubrik penilaian sebagai acuan dalam menentukan kriteria pelaksanaan blended learning di PAUD. Blended learning terdiri dari 4 indikator, yakni: fleksibilitas pembelajaran, interaksi, dorongan belajar aktif, fasilitasi proses pembelajaran. Indikator kemudian dirincikan lagi dalam bentuk pernyataan untuk mengetahui respon guru dalam pelaksanaan blended learning, peneliti menyebar google formulir yang berisi angket dengan bentuk pernyataan dan soal essai singkat. Kemudian hasil angket dianalisis menggunakan uji T, lalu hasil yang didapatkan secara kuantitatif dideskripsikan agar mudah dipahami. 


\section{HASIL DAN PEMBAHASAN}

Pelaksanaan belajar secara daring di PAUD lebih dikenal dengan istilah PAUD from home (PFH). PFH merupakan kegiatan PAUD yang diselenggarakan di rumah oleh keluarga bersama anak dengan petunjuk dan dampingan guru jarak jauh. Tentu saja PFH berbeda dengan belajar daring tingkat SD, SMP, SMA, dan Perguruan Tinggi. Jika sebelumnya layanan PAUD lebih fokus pada hubungan antara keluarga dan sekolah, maka covid-19 mengajarkan semua pihak untuk mengimplementasikan PAUD yang sesungguhnya dengan memperhatikan hubungan timbal balik antara lembaga, keluarga, dan lingkungan. Maka hal ini juga mendukung jargon Menteri Pendidikan Nadiem Makarim "merdeka belajar" dimana setiap tempat adalah sekolah, dan setiap orang adalah guru.

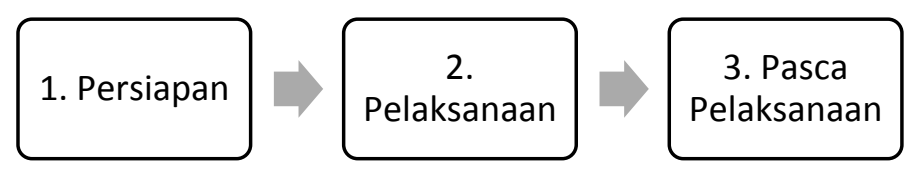

Gambar 2. Tahap Pelaksanaan PAUD from Home

Pembelajaran daring tingkat TK tidak serta merta dilaksanakan tanpa perencanaan yang matang, berikut tahap pelaksanaan PFH yang dilakukan melalui tiga tahap:

1. Tahap persiapan; tahapan ini dimulai dari memeriksa kondisi keluarga siswa, lalu memilih tipe belajar apakah daring, luring, atau belajar bauran (blended learning). Selanjutnya mempersiapkan anak, mempersiapkan orang tua, mempersiapkan rppm bertema, serta mempersiapkan panduan komunikasi antara guru dengan keluarga siswa.

2. Tahap pelaksanaan; keluarga berdiskusi dengan anak mengenai kegiatan yang akan dikirimkan, keluarga juga mencari berbagai sumber belajar (buku, video, gambar terkait tema, dan lain sebagainya), anak merdeka mengikuti ide guru atau idenya sendiri, adanya interaksi, anak bermain, dan dokumentasi kegiatan.

3. Tahap pasca pelaksanaan; keluarga melaporkan hasil PFH dengan mendokumentasikan kegiatan anak, anak diberikan kemerdekaan menyampaikan hasil kerjanya kepada guru, guru wajib menjawab setiap respon anak atau keluarga, guru melakukan penilaian pembelajaran \& tracker story, selanjutnya mengevaluasi dan menindak lanjuti PFH yang telah dilakukan.

Selain tiga hal di atas, lembaga juga perlu memberikan perangkat penguatan dengan cara menyiapkan perangkat pendukung yang diperlukan sesuai kondisi keluarga seperti: a) Alat dan bahan sesuai perencanaan, b) Narasi/penjelasan/video pijakan sebelum main untuk anak. c) Narasi/ penjelasan/video/foto parenting untuk keluarga. Agar PFH ini dapat berhasil, lembaga perlu memperhatikan prinsip 
keunikan setiap anak dan setiap keluarga itu berbeda, maka pendekatan PFH akan berbeda untuk setiap keluarga.

Berdasarkan angket yang telah disebar, kegiatan PFH akan divariasikan setiap hari. Mulai dari setoran hafalan yang biasanya dilakukan dengan panggilan video atau rekaman suara, peningkatan life skill dengan membantu pekerjaan orang tua di rumah, membuat berbagai hasil karya dengan bahan-bahan di sekitar lingkungan rumah, dan kegiatan fisik dengan alat-alat sedehana. Anak melakukan kegiatan didampingi keluarga yang kemudian di dokumentasikan dan dikirim ke guru. tidak ada tugas yang bersifat paksaan, semua dilakukan dengan penuh kerelaan dan fleksibel. Karena itu dalam hal ini perencanaan, pelaksanaan, pasca pelaksanaan, hingga penilaian kegiatan perlu dibuat dengan maksimal oleh sekolah.

Data yang dikumpulkan dan dianalisis adalah pengisian angket oleh guru dengan 14 soal pernyataan dan 3 soal essai singkat. Agar didapat gambaran penelitan secara umum dapat dlihat tabel deskripsi data penelitian. Dimana dari data tersebut dapat diketahui fungsi-fungs statistik mendasar.

Tabel 1. Rekapitulasi Hasil Angket Blended Learning

\begin{tabular}{llcccccc}
\hline No & \multicolumn{1}{c}{ Indikator } & $\begin{array}{c}\text { Jumlah } \\
\text { butir soal }\end{array}$ & $\begin{array}{c}\text { Skor } \\
\text { ideal }\end{array}$ & $\begin{array}{c}\text { Skor } \\
\text { faktual }\end{array}$ & N & Persentase & Kriteria \\
\hline $\mathbf{1}$ & $\begin{array}{l}\text { Fleksibilitas } \\
\text { pembelajaran }\end{array}$ & 4 & 480 & 381 & & $79,38 \%$ & Baik \\
$\mathbf{2}$ & $\begin{array}{l}\text { Interaksi } \\
\mathbf{3}\end{array}$ & 2 & 240 & 182 & 30 & $75,83 \%$ & Baik \\
& $\begin{array}{l}\text { Dorongan } \\
\text { belajar aktif }\end{array}$ & 4 & 480 & 395 & $82,29 \%$ & Baik \\
$\mathbf{4}$ & $\begin{array}{l}\text { Fasilitasi proses } \\
\text { pembelajaran }\end{array}$ & 4 & 480 & 326 & $67,91 \%$ & Baik \\
\hline
\end{tabular}

Berdasarkan tabel di atas dapat dijelaskan bahwa penerapan blanded learning pada indikator fleksibilitas program pendidikan memperoleh persentase sebesar $79,38 \%$ dan berada pada kategori baik, interaksi memperoleh persentase sebesar $75,83 \%$ dan berada pada kategori baik, dorongan belajar aktif memperoleh persentase sebesar $82,29 \%$ berada pada kategori baik dan terakhir pada indikator fasilitasi proses pembelajaran hanya memperoleh persentase sebesar $67,91 \%$ namun tetap berada pada kategori baik. Selanjutnya dibutuhkan kurva normal untuk melihat efektivitas blended learning, kriteria penilaian diperoleh melalui perhitungan dibawah ini:

$$
\begin{aligned}
\text { Mean } & =\frac{N \max -N \min }{2}+N \min & \mathrm{SD} & =\frac{\text { mean }}{13} \\
& =\frac{56-14}{2}+14 & & =\frac{35}{13} \\
& =21+14 & & =2,69 \\
& =35 & &
\end{aligned}
$$




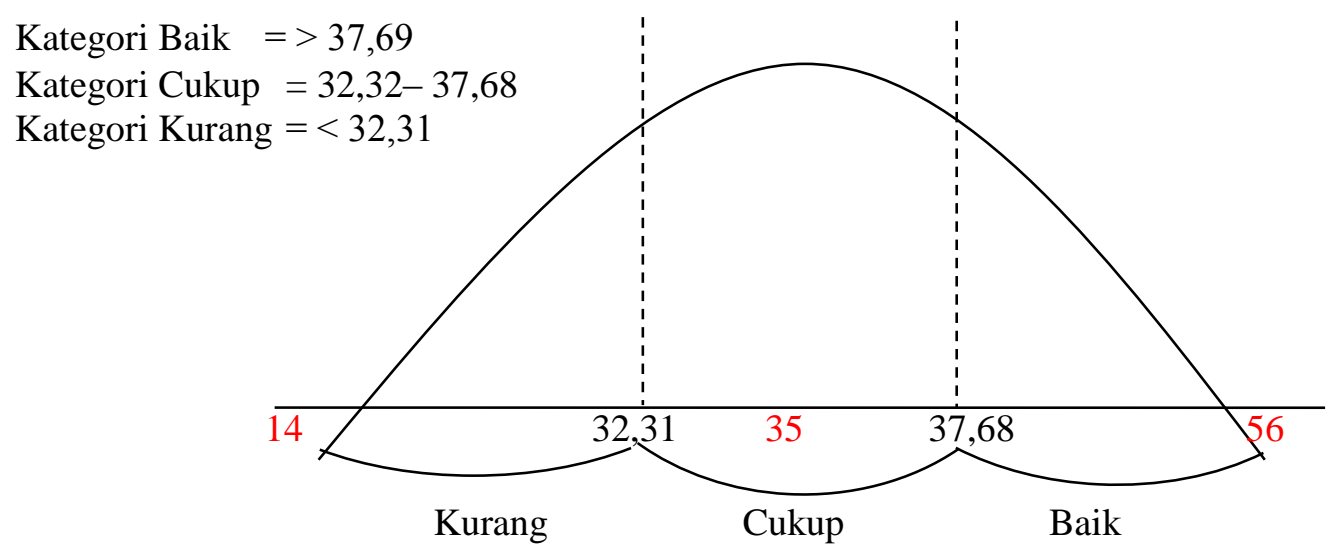

Gambar 3. Kurva normal

Berdasarkan grafik di atas, diketahui bahwa blended learning berada pada kategori baik untuk diterapkan pada pendidikan anak usia dini. Selanjutnya dilakukan uji asumsi, jenis uji asumsi yang dilakukan adalah uji normalitas dan uji homogenitas. Uji asumsi atau hipotesis digunakan untuk memverifikasi hipotesis penelitian dan ketika hasil Asym. Sig < 0,05 maka ini menunjukkan bahwa hipotesis tersebut (Sugiyono, 2016 hal. 67). Hasilnya akan disajikan pada tabel berikut:

Tabel 2. Uji Normalitas

\begin{tabular}{|l|l|r|}
\hline \multicolumn{2}{|c|}{ One-Sample Kolmogorov-Smirnov Test } \\
\hline \multicolumn{2}{|l|}{} & Blended_Learning \\
\hline \multirow{2}{*}{ Normal Parameters ${ }^{a, b}$} & Mean & 30 \\
\cline { 2 - 3 } & Std. & 42.8000 \\
& Deviation & 2.65746 \\
\hline Most Extreme Differences & Absolute & .118 \\
\cline { 2 - 3 } & Positive & .118 \\
\cline { 2 - 3 } & Negative & -.082 \\
\hline \multicolumn{2}{|l}{} & .118 \\
\hline Test Statistic & $.200 c, d$ \\
\hline Asymp. Sig. (2-tailed)
\end{tabular}

Berdasarkan hasil tabel di atas maka diiketahui nilai sig sebesar 0.200 yang artinya nilai tersebut lebih besar dari 0,05 maka data berdistribusi normal. Selanjutnya dilakukan uji homogenitas yang bertujuan untuk memberikan keyakinan bahwa sekumpulan data yang dimanipulasi dalam serangkaian analisis berasal dari populasi yang tidak jauh berbeda keragamannya. Hasil dari Uji Homogenitas dapat dilihat pada tabel berikut:

Tabel 3. Uji Homogenitas

\begin{tabular}{|l|r|}
\hline \multicolumn{2}{|c|}{ Test Statistics } \\
\hline & \multicolumn{2}{|c|}{ Blended_Learning } \\
\hline Chi-Square & $8.867 \mathrm{a}$ \\
\hline Df & 10 \\
\hline Asymp.Sig. & .545 \\
\hline
\end{tabular}

Berdasarkan tabel di atas diperoleh nilai Asymp sig sebesar 0.545. Nilai tersebut lebih besar dari 0,05. Sehingga dapat disimpulkan bahwa data homogen atau berasal dari populasi yang tidak jauh berbeda keragamannya. Setelah uji homogenitas 
dilakukan uji hipotesis, uji hipotess dilakukan untuk memperkuat keputusan apakah hipotesis diterima atau ditolak. Hasil uji hipotesis disajikan pada tabel berikut:

Tabel 4. Uji Hipotesis

\begin{tabular}{|c|c|c|c|c|c|c|}
\hline \multicolumn{7}{|c|}{ One-Sample Test } \\
\hline & \multicolumn{6}{|c|}{ Test Value $=0$} \\
\hline & \multirow[b]{2}{*}{$\mathrm{t}$} & \multirow[b]{2}{*}{ df } & \multirow[b]{2}{*}{ Sig. (2-tailed) } & \multirow[b]{2}{*}{ Mean Difference } & \multicolumn{2}{|c|}{ 95\% Confidence Interval of the Difference } \\
\hline & & & & & Lower & Upper \\
\hline Blended_Learning & 88.214 & 29 & .000 & 42.80000 & 41.8077 & 43.7923 \\
\hline
\end{tabular}

Berdasarkan tabel di atas menunjukkan nilai Sig ( 2 tailed) sebesar 0,000 artinya nilai sig < 0,05 maka dapat dikatakan bahwa hipotesis $\mathrm{H}_{\mathrm{a}}$ diterima atau $\mathrm{H}_{\mathrm{o}}$ ditolak, yang berarti bahwa bahwa blanded learning efektif untuk anak usia dini. Dari indikator fleksibilitas memperoleh skor tertinggi, karena blended learning tidak hanya menyediakan pembelajaran di kelas, selain itu waktu, media, tempat, bervariasi sehingga membuat siswa tidak terpaku pada berbaga keterbatasan. Indikator interaksi juga berada pada kategori baik, hal ini karena siswa tetap dapat berinteraksi dengan guru dan teman meski hanya melalui teknologi, namun interaksi dengan keluarga semakin erat. Indikator dorongan belajar aktif berada pada kategori baik, hal ini karena motivasi internal siswa meningkat dan pembelajaran tidak hanya memfokuskan pada aspek kognitif namun juga keamanan psikologis siswa. Selanjutnya indikator fasilitasi pembelajaran juga berada pada kategori baik, hal ini karena guru memberikan siswa kebebasan memilih dan memodifikasi tugas yang diberikan, serta menyediakn sumber belajar yang lebih variatif.

Secara umum, penelitian telah menemukan bahwa blended learning berpotensi meningkatkan proses pembelajaran, menghasilkan peningkatan dalam keberhasilan dan kepuasan siswa, serta peningkatan dalam kepekaan komunitas bila dibandingkan dengan pembelajaran klasikal (Garrison dan Kanuka 2014, hal. 102; Picciano 2014, hal. 65; Dziuban et al. 2016, hal. 45 ; Means et al. 2013, hal. 44; Rovai dan Jordan 2013, hal. 14). Blended learning, karena fleksibilitasnya, memungkinkan untuk memaksimalkan banyak fungsi pendidikan positif, dengan memanfaatkan teknologi yang ada, proses pembelajaran juga dapat terjadi dan dibuat lebih menyenangkan, mempengaruhi perolehan keterampilan teknologi, memprioritaskan pembelajaran siswa, manajemen waktu, dan suasana belajar yang inovatif.

Berdasarkan tinjauan teoritis dari Carman (2015, hal. 170) terungkap bahwa ada lima kunci untuk menerapkan blended learning seperti: 1) Live Event, pembelajaran langsung atau tatap muka (instruksi yang dipimpin instruktur) serentak di waktu dan tempat yang sama (ruang kelas) atau waktu yang sama tetapi tempat yang berbeda (ruang kelas virtual). 2) Pembelajaran Mandiri, yaitu menggabungkan dengan belajar mandiri (self-learning) yang memungkinkan siswa untuk belajar kapan saja, di mana saja menggunakan berbagai konten (bahan pembelajaran) yang dirancang khusus untuk pembelajaran mandiri baik berbasis teks dan berbasis multimedia (video, 
animasi, simulasi, gambar, audio, atau kombinasi dari semuanya). 3) Kolaborasi, kerjasama guru dan siswa dalam proses pembelajaran dapat mencakup proses transfer pengetahuan. 4) Penilaian, dalam blended learning, perancang harus dapat membuat kombinasi jenis penilaian baik tes dan nonest, atau tes yang lebih otentik (penilaian / portofolio otentik). 5) Bahan pendukung kinerja lainnya; berbagai sumber belajar yang bergam.

\section{SIMPULAN}

Mencampurkan pembelajaran klasikal dan daring merupakan hal baru yang menguji keterampilan adaptasi semua orang yang terlibat didalamnya. Berdasarkan hasil penelitian, blended learning efektif diterapkan untuk anak usia dini. Hal ini tentu karena komunikasi yang baik antar semua pihak, mulai dari pemerintah, lembaga pendidikan, orang tua, hingga anak. Namun penerapan blended learning di PAUD perlu memperhatikan beberapa hal, seperti konsep kesenjangan digital di mana beberapa bagian masyarakat kekurangan sarana digital dan / atau literasi untuk mendapatkan manfaat dari perluasan akses. Pertimbangan penting lainnya dalam efektivitas blended learning adalah motivasi, karena siswa banyak diberikan kesempatan untuk berlatih menafsirkan sehingga perlu diingatkan agar fokus pada tujuan pembelajaran. Pada dasarnya blended learning memiliki pola interaksi yang berbeda, jenis pekerjaan rumah yang berbeda, keberagaman media, dan lebih banyak variasi dalam pembelajarannya. Peran guru dan keluarga yang berubah adalah masalah dasar dari blended learning. Tantangan-tantangan ini dapat dipertimbangkan oleh para peneliti dan praktisi di masa depan dalam merancang blended learning khususnya untuk anak usia dini.

\section{DAFTAR PUSTAKA}

Atlay, Ismail Furat dan Atlay Ayse. 2019. A review of studies on blended learning in efl environment. International journal of curriculum and instruction 11 (1) 2019

Bersin, Steed. 2014. Teacher conceptions of blended learning, blended teaching and associations with approaches to design. Australasian Journal of Educational Technology, 22(3), 312-335

Boelens, R., De Wever, B., \& Voet, M. 2017. Four key challenges to the design of blended learning: A systematic literature review. Educational Research Review, 22(4), 1-18. doi:https:// doi.org/10.1016/j.edurev.2017.06.001

Carman, J. M. 2015. Blended Learning Design: Five Key Ingredients. Blended Learning Design: 5 Key Ingredients, International Journal of Linguistics, Literature, and Translation (IJLLT). 2(3), 166-174

Chew E., Jones N., Turner D. Critical Review of the Blended Learning Models Based on Maslow's and Vygotsky's Educational Theory' in Hybrid Learning and Education. Berlin, Springer Verlag Publ., 2008, pp. 40-53. DOI: 10.1007/978-3-540-85170-7_4

Depdiknas, 2003. Undang-undang RI No. 20 Tahun 2003 Tentang Sistem Pendidikan Nasional. Jakarta: Depdiknas

Dziuban et al. 2018. Blended learning: the new normal and emerging technologies. International journal of educational technology in higher education. No $15 \mathrm{v} 3$. Doi: 10.1186/s41239-017-0087-5 
Dziuban, C., Picciano, A. G., Graham, C. R., \& Moskal, P. D. 2016. Conducting research in online and blended learning environments: New pedagogical frontiers. New York: Routledge, Taylor \& Francis Group

Garrison, D. R., \& Kanuka, H. 2014. Blended learning: Uncovering its transformative potential in higher education. Internet and Higher Education, 7, 95 -105. https://doi.org/10.1016/j.iheduc.2004.02.001

Husamah. 2014. Pembelajaran Bauran (Blended Learning) Terampil Memadukan Keunggulan Pembelajaran Face-To-Face, ELearning Offline-Online, Dan Mobile Learning. Jakarta: Prestasi Pustaka

Ikhwan, Eisha. Jamila Q., Widodo, Pratomo. 2019. Attitude Conception: The Role of Blended Learning in Environmental Education. International Journal of Linguistics, Literature and Translation (IJLLT) 2 (6). DOI: 10.32996/ijllt.2019.2.6.7

Krasnova T. 2014. A Paradigm Shift: Blended Learning Integration in Russian Higher Education. Procedia - Social and Behavioral Sciences, 2015, no. 166, pp. 399-403. DOI: 10.1016/j.sbspro.2014.12.543

Lalima., kirana lata dangwal. 2017. Blended learning: an innovative approach. Universal Journal of Educational Research 5(1): 129-136, 2017. DOI: 10.13189/ujer.2017.050116

Launer R. 2010. Five Assumptions on Blended Learning: What Is Important to Make Blended Learning a Successful Concept? Hybrid Learning. Berlin: Springer Verlag

Margulieux, L. E., Bujak, K. R., McCracken, W. M., \& Majerich, D. M. 2014. Hybrid, blended, flipped, and inverted: Defining terms in a two dimensional taxonomy. In Paper accepted to the 12th Annual Hawaii International Conference on Education. Honolulu, HIJanuary (Vol. 2014, pp. 5-9)

Means, B., Toyama, Y., Murphy, R., \& Baki, M. (2013). The effectiveness of online and blended learning: A meta-analysis of the empirical literature. Teachers College Record, 115(3), 147

Picciano, A. G., Dziuban, C., \& Graham, C. R. 2014. Blended learning: Research perspectives, (vol. 2). New York: Routledge

Rovai, A.P., Jordan J.I. 2013. In search of higher persistence rates in distance education online programs. Computer \& education, 6(1) 1-16

Seraji, Farhad., Attaran, Muhammad., Azizi, Sayyed Mohsen,. 2019. Blended Learning Researches in Iran: Several Fundamental Criticisms. Digital Education Review Number 36, December 2019- http://greav.ub.edu/der/ Blended Learning Researches in Iran: Several Fundamental Criticisms

Staker, H., \& Horn, M. B. 2012. Classifying K-12 blended learning. Innosight Institute Sugiyono. 2016. Metode Penelitian Kuantitatif, Kualitatif, dan REDD. Bandung: PT. Alfabet

Tucker, C. R. (2012). Blended learning in grades 4-12: Leveraging the power of technology to create student-centered classrooms. Thousand Oaks, CA: Corwin. 